\title{
INTERNET DAN MUSIK: MEDIA SOSIAL SEBAGAI WAHANA PUBLIKASI THE UPSTAIRS DAN DEATH FLAMES
}

\author{
Sujud Puji Nur Rahmat ${ }^{1}$, Lono Simatupang ${ }^{2}$, Harsawibawa Albertus ${ }^{3}$
}

\begin{abstract}
Nowdays internet has become an important elemen in people life across the globe. Its impact has been seen in various scenes including music business and other artistic fields. Social media, running in support of internet, are now common in use by musicians or bands. Free of charge and global access of internet and social media provide an opportunity to disseminating the existence of a group of musicians. In this paper I would to show how social media has been utilized by a band to promote their group by themselves, focusing on myspace account of two bands, The Upstairs and death Flames. I divide this paper into introduction, an overview of www.myspace.com as well as a brief profile of the two bands, and a discussion on their account, kinds of responses and communication that established based on the accounts.
\end{abstract}

Keywords: internet, musicians, band, and disseminating

\begin{abstract}
Abstrak
Saat ini internet telah menjadi salah satu elemen penting dalamkehidupan manusia di berbagai belahan dunia. Dampaknyaterlihat dalam berbagai aspek, termasuk bisnis musik dan ranah-ranah artistik lainnya. Media sosial, yan dijalankan dengan dukungan internet, kini umum digunakan oleh para musisi atau band. Penggunaan media sosial yang tidak berbayar alias gratis memungkinkan kelompok-kelompok musisi menyebarluaskan eksistensi mereka bahkan hingga ranah global. Dalam tulisan ini penulis mencoba memperlihatkan bagaimana media sosial digunakan oleh kelompok musik untuk mempromosikan kelompoknya, dengan mengambil contoh dua akun media sosial, yakni milik The Upstairs dan Death Flames. Tulisan ini terdiri dari pengantar, selayang pandang tentang situs www.myspace.com, kelompok The Upstairs dan Death Flames, serta diskusi soal akun-akun tersebut, macam-macam respon terhadapnya, serta komunikasi macam apa yang muncul dalaminteraksi-interaksi itu.
\end{abstract}

Kata kunci: Internet, musisi, band, dan diseminasi.

\footnotetext{
${ }^{1}$ Mahasiswa S-3 di Prodi PSPSR, Sekolah Pascasarjana UGM. Gedung Lengkung Jalan Teknika Utara, Pogung Yogyakarta. Email: sujud_pnr@yahoo.com

${ }^{2}$ Promotor di Prodi PSPSR, Sekolah Pascasarjana UGM. Gedung Lengkung Jalan Teknika Utara, Pogung Yogyakarta.

${ }^{3}$ Co Promotor di Prodi PSPSR, Sekolah Pascasarjana UGM. Gedung Lengkung Jalan Teknika Utara, Pogung Yogyakarta.
} 


\section{Pendahuluan}

Hadirnya teknologi di tengah masyarakat, baik di di kota-kota besar seperti Jakarta bahkan hingga pelosok-pelosok daerah, memiliki dampak yang berarti, sebab teknologi ini memudahkan beragam aktivitas, baik dalam rumah maupun di luar rumah. Dalam perjalanannya, teknologi menjadi kebutuhan sehari-hari dan kebiasaan seharihar. Teknologi semakin lama semakin berkembang, dan ini memungkinkan manusiauntuk melakukan berbagai hal.

Sebagai makhluk sosial, manusia selalu ingin berinteraksi dengan orang lain. Saat ini, interaksi antara manusia yang satu dengan yang lainnya banyak diperantarai oleh teknologi komunikasi. Banyak sekali teknologi komunikasi yang diciptakan dan terus dikembangkan, misalnya adalah internet ${ }^{4}$. Internet dapat dipergunakan tanpa mengenal waktu (24 jam sehari/7 hari dalam seminggu), tanpa mengenal batas wilayah (digunakan dinegara mana saja dan ditujukan ke negara mana saja), umur pengguna, jenis kelamin, pekerjaan, suku, agama, warna kulit, dan dapat digunakan untuk siapa saja.Kini, mengakses internet tidak hanya bisa dilakukan melalui komputer saja, melainkan juga dapat melalui telepon seluler (ponsel) atau telepon genggam, PDA (personal digital assistant), dan bahkanpesawat televisi.Dengan menggunakan internet semua orang bisa mendapatkan informasi dan juga dapat menginformasikan, mulai dari kesenian, ekonomi, politik, olahraga dan Iain-lain. Internet, sebagai media baru, seolah meruntuhkan batas-batas kaku ruang dan waktu, memungkinkan banyak tempat yang secara geografis berjauhan bisa terhubung dalam satu waktu, meningkatkan keterhubungan, serta dapat juga mendorong migrasi dan diaspora (Ewa Mazierska, 2015: 3).

Keberadaan internet antara lain memicu kemunculan situs layanan jejaring sosial yang memungkinkan para pengguna internet berhubungan karena kesamaan sosialitas. Layanan jejaring sosial menyediakan cara yang beragam bagi pengguna internet untuk dapat berinteraksi seperti chatting, messenger, email, video, voice chat, share file, blog,

${ }^{4}$ Internet merupakan revolusi teknologi yang memungkinkan semua komputer di dunia terhubung ke suatu jaringan. Internet barasal dari kata interconnected networking yang dalam bahasa Indonesia bermakna jaringan komputer yang saling berhubungan. Dengan menggunakan internet, komputerkomputer di seluruh dunia dapat bertukar data dan informasi. Tidak hanya itu, dengan menggunakan internet para penduduk dunia juga dapat saling berkomunikasi menggunakan layanan internet seperti surat elektronik. Lihat Ali Akbar, Kamus Praktis Internet: Untuk Semua Orang (Semarang: Neomedia Press, 2006), 87-88. 
diskusi grup, dan Iain-lain. Umumnya layanan jejaring sosial memberikan layanan bagi pengguna untuk membuat biodata dirinya. Pengguna dapat mengunggahfoto dirinya dan dapat menjadi teman dengan pengguna lainnya. Beberapa layanan jejaring sosial memiliki fitur tambahan seperti pembuatan grup agar para penggunanya bisa saling berbagi konten informasi. Dalam konteks musik populer, internet merupakan sebuah perangkat untuk mendistribusikan dan mengkonsumsi musik, serta untuk wahana komunikasi antara artis dengan penggemarnya (Kristopher, 2016: 5).

Salah satu layanan jejaring sosial adalah situs www.myspace.com yang berdiri sejak tahun 2003, berkantor pusat di Beverly Hills, California, Amerika Serikat. Jenis anggota situs www.myspace.com terbagi menjadi 4 kategori, yakni perorangan, band/musisi, comedians, dan filmmakers. Pengguna situs ini yang merupakan band/musisi cukup banyak dan berasal lebih dari 150 negara dan setiap tahunya pun bertambah. Jenis musik setiap masing-masing band/musisi pun berbeda-beda, yang hingga saat ini ada lebih dari 100 jenis musik. Band/musisi Indonesia yang menggunakan situs ini juga relatif banyak. Band/musisi Indonesia yang menggunakan situs www.myspace.commisalnya adalah kelompok musik The Upstairs dan Death Flames.

Lewat situs-situs jejaring sosial seperti myspace, musisi bisa membangun citra dirinya, memperlihatkan eksistensinya kepada publik lewat unggahan-unggahan mereka, baik itu profil, aktivitas, maupun informasi-informasi seputar kelompokitu maupun hal-hal lain yang terasosiasikan dengan diri atau kelompoknya. Jangkauan internet yang begitu luas memungkinkan musisi mempublikasikan dan mempromosikan dirinya dengan jangkauan yang tak terbatas alias global. Dengan kata lain, situs jejaring sosial menjadi salah satu wahana komunikasi musisi dengan publik.

Tulisan ini berusaha memperlihatkan bagaimana sistus jejaring sosial digunakan untuk tujuan-tujuan itu, yakni: bagaimana kelompok musik menampilkan dirinya pada publik, dan respon apa saja yang diperoleh dari publik. Untuk memberikan gambaran yang bermakna, tulisan ini menyoroti aktivitas publikasi kelompok The Upstairs dan Death Flames. 


\section{WWW.MYSPACE.COM, THE UPSTAIRS, DAN DEATH FLAMES}

Situs www.myspace.com menyediakan banyak layanan atau fasilitas. Mulanya, situs www.myspace.com dimiliki oleh perusahaan www.yourz.com. Dahulu situs ini diharapkan menjadi penyimpanan data daring terkemuka sampai tahun 2002. Pada tahun 2004, www.myspace.com berkerjasama dengan situs www.yourz.com, dan bermetamorfosa dari sebuah situs penyimpanan virtual menjadi sebuah situs layanan jejaring sosial.Situs www.myspace.com dapat diatur oleh pengguna untuk merepresentasikan suasana hati/status (berupa gambar emosi kecil), tampilan profil berisi uraian singkat: "tentang saya" dan "siapa yang ingin saya temui" (profil juga memuat bagian "minat" dan bagian "perincian"), blog, gambar (salah satu dari gambargambar tersebut dapat dipilih untuk menjadi gambar utama yang akan terpampang pada halaman utama profil, halaman pencarian, dan sebagai gambar yang akan muncul di samping nama pengguna pada komentar, pesan, dan sebagainya. Ada pula tempat "komentar", sehingga teman dari pengguna dapat memberikan tanggapan.

Profil-profil situs www.myspace.com untuk para anggota band/musisi berbeda dari profil-profil anggota lainnya. Di akun miliknya, anggota band/musisi dimungkinkan untuk menyimpan maksimal 6 lagu berformat MP3. Penyimpan harus memiliki hak untuk menggunakan lagu-lagu tersebut. Kendati demikian, ada kesamaan pengaturan profil pribadi anggota band/musisi, dengan jenis anggota personal, comedians dan filmmakers. Berikut isi untuk mengatur profil di dalam anggota band/musisi.

Di antara pengguna www.myspace.com yang merupakan kelompok musik asal Indonesia adalah The Upstairs. The Upstairs terbentuk pada oktober tahun 2001, dipunggawai oleh Jimi Multhazam (vokalis) dan Kubil Idris (gitaris). Setelah beberapa bulan, posisi penabuh drum diisi oleh Beny Adhiantoro yang merupakan drummer band metalcore "Straightout", disusul oleh Alfi Chaniago yang mengisi posisi pembetot bass. Kebetulan semuanya adalah mahasiswa Institut Kesenian Jakarta (IKJ).Pada awalnya band ini terpengaruh oleh sound klasik rock 70-an seperti Buzzcocks dan The Damned. Perjalanan karir The Upstairs dimulai pada awal 2002dengan merilis mini album bertajuk"Antahberantah" dalam bentuk kaset dan CD. Dalam waktu singkat, 300 keping terjual habis. Untuk mempromosikan mini albumnya itu,The Upstairs juga mengadakan 
konser di Jakarta, Bandung dan Yogyakarta. Setelah merilis mini album, mereka juga melakukan serangkaian partisipasi album kompiliasi, misalnya album kompilasi “Kampus 24 Jam hits Vol. 1"yang diproduksi dan diedarkan oleh Kampus 24 Jam pada tahun 2002 dan album kompilasi "JKT:SKRG"yang diproduksi dan diedarkan oleh Aksara Records pada tahun 2003.Pada tanggal 14 Februari 2004 The Upstairs merilis album pertama yang diberi judul "Matraman" di produksi dan diedarkan oleh Sirkus Records. Pada tanggal yang sama diselenggarakan konser pengenalan atau peluncuran album pertamanya di bar BB's, kawasan Menteng, Jakarta. Dalam waktu dua jam sejak konser itu dimulai atau pintu masuk dibuka, 100 buah CD album "Matraman" habis terjual.

Pada bulan Maret The Upstairs melakukan pembuatan video klip dari salah satu lagunya yang berjudul “Apakah Aku Berada Di Mars atau Mereka Mengundang Orang Mars", tanggal 6 April 2004melakukan wawancara sekaligus live broadcasting di program acara MTV Cutting Edge. Pada awal Mei 2004, “Apakah Aku Berada Di Mars atau Mereka Mengundang Orang Mars" masuk dalam urutan nomor wahid di programprogram stasiun radio swasta MTV Sky J AMU (Jajaran Musik Unggulan) selama dua minggu berturut-turut. Sementara di stasiun-stasiun radio swasta lainnya seperti Prambors, I-Radio, U-FM, MTV Sky Jogj a, MTV Sky Semarang, Swaragama hingga Oz FM, salah satu lagu The Upstairs berhasil masuk kedalam jajaran sepuluh besar lagu-lagu terbaik selama berminggu-minggu.Profil The Upstairs pun kerapkali dimuat dalam majalah-majalah di tanah air seperti majalah MTV Trax, majalah GADIS, majalah Hai, majalah Cosmogirl, majalah Aneka, dan majalah Poster.Pada akhir Mei 2004 video yang berjudul "Apakah Aku Berada di Mars atau Mereka Mengundang Orang Mars" ditayangkan di MTV Indonesia untuk pertama kalinya.Pada 1 Agustus 2004 album kedua The Upstairs berjudul "Matraman" dirilis dalam format kaset dengan pendistribusian secara nasional oleh label RNB.

Perjalanan The Upstairs yang relatif sukses ini dikarenakan tidak luput dari dukungan para Modar (Modern Darling) sebutan untuk para penggemar The Upstairs. Maret 2005 The Upstairs diminta oleh FFWD Records untuk berpartisipasi di album soundtrack film Catatan Akhir Sekolah. Dan masih di tahun 2005, Agus Sasongko seorang Artis and Repertoire Executive dari Warner Music Indonesia menangkap gelombang yang digelontorkan The Upstairs dan segera menawarkannya dengan sebuah 
kontrak rekaman eksklusif.Setelah kesuksesan album "Matraman", The Upstairs, pada bulan September 2005, dikontrak satu album oleh major label internasional Warner Music Indonesia dan merilis Energy secara nasional pada Maret 2006. Album yang melejitkan "Terekam (Tak Pernah Mati)" dan "Disko Darurat" sebagai hits ini menandai sukses gemilang sebuah band indie yang awalnya divonis "aneh" oleh publik hingga menjadi band cult yang diakui reputasinya di tingkat nasional. Penghargaan yang diperoleh antara lain The Best Indie Album 2004(Majalah MTV Trax), The Best Indie Band 2004 dan "Penguasa Baru Jakarta"(Majalah HAI), "Grup Alternatif Terbaik" (AMI Awards 2006), "Band Pelopor Kreativitas Pemuda" (Menpora), "Raja Pensi 2006” (Majalah Gadis), dan “The New Color”tahun 2007 (Editors' Choice Awards 2007 Majalah Rolling Stone Indonesia).

Kelompok musik Indonesia lainnya yang menggunakan myspace untuk menunjukkan eksistensinya adalah Death Flames. Kelompok ini berdiri tanggal 5 november 2007, sebelumnya bernama Emily Rose. Pada awal tahun 2006 sampai pertengahan tahun 2008 kelompok ini sering mengisi pertunjukan musik di Jakarta. Tepat pada bulan maret tahun 2007, mereka terlibat dalam pembuatan album kompilasi "Kampus 24 Jam Non Stop Hits Vol. 2" dengan menyumbangkan 1 buah lagu berjudul "Brutallity Of Life". Album kompilasi ini diinisisasi oleh mahasiswa-mahasiswi Institut Kesenian Jakarta, dan para pengisi kompilasi tersebut hanyalah kelompok musik yang berasal dari kampus tersebut.

\section{AKUN MYSPACE THE UPSTAIRS DAN DEATHFLAMES}

\section{A. Konten dan Respon terhadap Akun}

Berikut ini akan dipaparkan data-data sekaligus ulasan tentang konten yang dimuat dalam akun myspace The Upstairs dan Death Flames, respon terhadap informasi itu, serta konten komunikasi yang terjadi. Untuk mempermudah pembacaan informasi, data-data disajikan dalam tabel sederhana. 
Tabel 1.

Tampilan Akun MySpaceThe Upstairs dan Death Flames

\begin{tabular}{|c|c|c|c|}
\hline $\begin{array}{c}\text { Kategori } \\
\text { Informasi }\end{array}$ & Deskripsi & The Upstairs & Death Flames \\
\hline \multirow[t]{8}{*}{ Band Name } & Band Name & $\begin{array}{l}\text { The Upstairs (Finishing } \\
\text { AlbumCover) }\end{array}$ & Deathflames \\
\hline & Genre & new wave/rock & $\begin{array}{l}\text { Metal, Progressive, } \\
\text { Experiment }\end{array}$ \\
\hline & $\begin{array}{l}\text { Primary } \\
\text { Picture }\end{array}$ & $\begin{array}{l}\text { foto personilThe Upstairs dengan } \\
\text { kostum ala kelompok musik } \\
\text { Indonesia lain }\end{array}$ & background \\
\hline & Headline & Official Myspace Page & $\begin{array}{l}\text { The Official DEATHFLAMES } \\
\text { Myspace Page }\end{array}$ \\
\hline & City & Jakarta & Jakarta \\
\hline & Country & Indonesia & Indonesia \\
\hline & Profile Views & 173.896 & 3.355 \\
\hline & Last Login & $4 / 27 / 2008$ & $10 / 21 / 2008$ \\
\hline $\begin{array}{l}\text { View My } \\
\text { Pics }\end{array}$ & View My Pics & Foto dan video & Foto dan video \\
\hline $\begin{array}{l}\text { Kotak } \\
\text { Otomatis }\end{array}$ & $\begin{array}{c}\text { Kotak } \\
\text { Otomatis }\end{array}$ & Standar & Standar \\
\hline $\begin{array}{l}\text { URL } \\
\text { MySpace }\end{array}$ & $\begin{array}{c}\text { URL } \\
\text { MySpace }\end{array}$ & $\begin{array}{l}\text { http://www.myspace.com/theupst } \\
\text { airsl }\end{array}$ & $\begin{array}{l}\text { http://www.myspace.com/withdeathfla } \\
\text { me }\end{array}$ \\
\hline \multirow[t]{7}{*}{$\begin{array}{l}\text { General } \\
\text { Info }\end{array}$} & $\begin{array}{l}\text { Member } \\
\text { Since }\end{array}$ & $10 / 13 / 2005$ & $11 / 13 / 2007$ \\
\hline & Band Website & theupstairsl .multiply.com & - \\
\hline & $\begin{array}{l}\text { Band } \\
\text { Member }\end{array}$ & $\begin{array}{l}\text { Jimi Multhajam, (vocal),Kubil } \\
\text { Idris (gitar), Beni Adhiantoro } \\
\text { (drum), Alfi Chaniago (bass \& } \\
\text { keyboards), Dian Maryana } \\
\text { (backing vocal), Former Member: } \\
\text { Elta Emanuella (keyboards) }\end{array}$ & $\begin{array}{l}\text { Zhaer (throat), Pamong (guitar), Ijal } \\
\text { (guitar), Iman(bass), Ricky (drum), } \\
\text { Inand (keys, piano, synth) }\end{array}$ \\
\hline & Influences & $\begin{array}{l}\text { A Flock of Seagulls, Joy } \\
\text { Division, Lou Reed, Iggy Pop, } \\
\text { DEVO }\end{array}$ & $\begin{array}{l}\text { Pantera, Slayer, Barones, Johan } \\
\text { Sebastian Bach, Symphony X, } \\
\text { Opeth, Death, Spastic Ink, Virulence } \\
\text { dan Dream Theater }\end{array}$ \\
\hline & Sound Like & Bookings ... & $\begin{array}{l}\text { Insanity, Sadnes, Glory!!, Heavy } \\
\text { experiment Metal }\end{array}$ \\
\hline & Record Label & Warner Music Indonesia & - \\
\hline & $\begin{array}{l}\text { Type Of } \\
\text { Label }\end{array}$ & Major & unsigned \\
\hline $\begin{array}{l}\text { Manage } \\
\text { Songs }\end{array}$ & $\begin{array}{l}\text { Manage } \\
\text { Songs }\end{array}$ & $\begin{array}{l}\text { Menampilkan } 4 \text { lagu dengan } \\
\text { pengaturannya }\end{array}$ & $\begin{array}{l}\text { Menampilkan } 3 \text { lagu beserta } \\
\text { pengaturannya }\end{array}$ \\
\hline $\begin{array}{l}\text { Upcoming } \\
\text { Shows }\end{array}$ & $\begin{array}{l}\text { Upcoming } \\
\text { Shows }\end{array}$ & $\begin{array}{l}\text { Show Date: May } 10 \text { 2008", } \\
\text { "Show Time: 8:00pm", "Venue: } \\
\text { STT TELKOM NITE@ STUDIO } \\
\text { EAST, Bandung" dan "City: } \\
\text { Bandung }\end{array}$ & - \\
\hline $\begin{array}{l}\text { Latest Blog } \\
\text { Entry }\end{array}$ & $\begin{array}{l}\text { Latest Blog } \\
\text { Entry }\end{array}$ & 5 buah tulisan & - \\
\hline About & About & $\begin{array}{l}\text { video konser dan tulisan (nama } \\
\text { lengkap personil, sejarah, profil- } \\
\text { dalam bahasa Indonesia dan } \\
\text { Inggris) }\end{array}$ & $\begin{array}{l}\text { Nama lengkap personil (dalam bahasa } \\
\text { Inggris), sejarah, profil (bahasa } \\
\text { Indonesia), alamat manajemen }\end{array}$ \\
\hline
\end{tabular}




\begin{tabular}{|c|c|c|c|}
\hline \multirow[t]{8}{*}{$\begin{array}{l}\text { Friend } \\
\text { Space }\end{array}$} & $\begin{array}{c}\text { Jumlah Hal. } \\
\text { Menampung } \\
\text { Teman }\end{array}$ & 200 Hal (@ 40 akun) & 25 Halaman (@40 akun) \\
\hline & All friends & 8.000 & 1.000 \\
\hline & Top Friends & 24 & 24 \\
\hline & $\begin{array}{l}\text { Online } \\
\text { Friends }\end{array}$ & Tentatif & Tentatif \\
\hline & New Friends & 5 halaman & Tidak tercantum \\
\hline & Bands & 10 halaman & 5 halaman \\
\hline & Comedians & 10 halaman & 5 halaman \\
\hline & Filmmakers & 10 halaman & 5 halaman \\
\hline \multirow{5}{*}{$\begin{array}{l}\text { Usia } \\
\text { Teman }\end{array}$} & Age18-24 & 10 halaman & 5 halaman \\
\hline & Age25-29 & 10 halaman & 5 halaman \\
\hline & Age 30-35 & 10 halaman & 5 halaman \\
\hline & Age 36-40 & 10 halaman & 5 halaman \\
\hline & Age 40+ & 10 halaman & 5 halaman \\
\hline $\begin{array}{l}\text { Friends } \\
\text { Comments }\end{array}$ & $\begin{array}{c}\text { Friends } \\
\text { Comments }\end{array}$ & 3.379 & 400 \\
\hline
\end{tabular}

Data yang dicantumkan pada tabel di atas diambil pada tanggal 28 April 2008 dan 22 Oktober 2018. Ini memperlihatkan adanya perbedaan dalam hal memanfaatkan akun sebagai media promosi dan publikasi serta seberapa banyak akun yang tertarik merespon keberadaan akun Myspace milik the Upstairs dan Death Flames.

Berdasarkan data di atas, terlihat bahwa the Upstairs memanfaatkan akun dengan lebih baik untuk mempromosikan kelompoknya, antara lain terlihat dari materi yang dipublikasikan tentang diri mereka (video konser, dilengkapi dengan sejarah, profil, dan sebagainya. Sementara itu, Death Flames memberikan informasi tentang diri mereka tidak seperti The Upstairs. Tetapi, dalam hal informasi kontak, Death Flames justru mencantumkan kontak manajemennya. Kendati demikian, lengkap tidaknya informasi yang ditampilkan di akun tidak menjadi satu-satunya tolak ukur keberhasilan. The Upstairs yang lebih dulu lahir dan sudah berhasil memasuki label rekaman mayor bisa jadi memiliki daya tarik yang lebih besar bagi para konsumen musik, sehingga teman di akunnya pun jauh lebih banyak dibandingkan Death Flames yang dalam hal usia jauh lebih muda dan belum berkesempatan rekaman dengan label mayor.

Data di atas lebih menunjukkan adanya perbedaan pemanfaatan akun dan besarnya pengikut atau teman yang tertarik dengan keberadaan suatu kelompok musik, tanpa serta merta mengajukan hipotesis soal keterkaitan antara perlakukan terhadap akun jejaring sosial dengan jumlah penggemar. 
Informasi lain soal akun jejaring sosial kelompok musik adalah jenis respon yang diterima oleh akun. Sejauh ini dapat dikategorikan empat kategori respon teman atau pengikut terhadap suatu akun, yani (1) mengunjungi profil, (2) mendengarkan karya, (3) menjadi teman, dan (4) memberikan komentar. Berikut ini disajikan data respon-respon tersebut terhadap akun Myspace The Upstairs dan Death Flames.

Tabel 2.

Respon terhadap Akun MySpace The Upstairs dan Death Flames

The Upstairs

\begin{tabular}{|l|r|r|r|r|r|r|r|}
\hline \multicolumn{1}{|c|}{ Jenis } & \multicolumn{1}{c|}{ 22 April } & \multicolumn{1}{c|}{ 23 April } & \multicolumn{1}{c|}{ 24 April } & \multicolumn{1}{c|}{ 25 April } & \multicolumn{1}{c|}{ 26 April } & \multicolumn{1}{c|}{ 27 April } & 28 April \\
\hline Profile Views & 169.895 & 170.407 & 171.091 & 171.602 & 172.134 & 172.976 & 173.896 \\
\hline Total Plays & 199.458 & 199.701 & 199.964 & 200.180 & 200.425 & 200.824 & 201.314 \\
\hline Lagu 1 & 55.897 & 56.055 & 56.237 & 56.383 & 56.534 & 56.774 & 57.050 \\
Lagu 2 & 31.795 & 31.833 & 31.865 & 31.904 & 31.933 & 32.007 & 32.083 \\
Lagu 3 & 75.015 & 75.039 & 75.068 & 75.084 & 75.1 .10 & 75.157 & 75.223 \\
Lagu 4 & 36.753 & 36.776 & 36.796 & 36.811 & 36.850 & 36.888 & 36.960 \\
\hline Plays Today & 256 & 105 & 129 & 113 & 120 & 246 & 164 \\
\hline Friends & 7.967 & 7.972 & 7.983 & 7.987 & 7.997 & 7.992 & 8.000 \\
\hline Comment & 3.357 & 3.358 & 3.361 & 3.367 & 3.369 & 3.372 & 3.379 \\
\hline
\end{tabular}

Sumber: Situs http://www.myspace.com/theupstairsl, 28 April 2008

\section{Death Flames}

\begin{tabular}{|l|r|r|r|r|r|r|r|}
\hline \multicolumn{1}{|c|}{ Jenis } & 16 Oktober & \multicolumn{1}{c|}{ 17 Oktober } & 18 Oktober & 19 Oktober & 20 Oktober & 21 Oktober & 22 Oktober \\
\hline Profile Views & 3.426 & 3.441 & 3.450 & 3.467 & 3.485 & 3.490 & 3.500 \\
\hline Total Plays & 1.362 & 1.387 & 1.412 & 1.437 & 1.462 & 1.487 & 1.500 \\
\hline Lagu 1 & 864 & 870 & 876 & 882 & 888 & 894 & 900 \\
Lagu 2 & 326 & 330 & 334 & 338 & 342 & 346 & 350 \\
Lagu 3 & 232 & 235 & 238 & 241 & 244 & 247 & 250 \\
\hline Plays Today & 11 & 15 & 9 & 17 & 18 & 15 & 10 \\
\hline Friends & 982 & 985 & 988 & 991 & 994 & 997 & 1.000 \\
\hline Comment & 378 & 380 & 392 & 394 & 396 & 398 & 400 \\
\hline
\end{tabular}

Sumber: Situs http://www.myspace.com/withdeathflme, 22 Oktober 2008

\section{B. Komunikasi yang Terjadi}

Secara umum, komunikasi yang terjadi antara kelompok musik dan penggemarnya lewat perantara akun media sosial Myspace dapat dikategorikan menjadi 4 jenis berdasarkan sifatnya, yakni (1) komentar, (2) memberi informasi, (3) meminta informasi, dan (4) menyapa. Yang termasuk komentar misalnya berupa ucapan selamat atau pujian; memberi informasi misalnya unggahan tentang proses pembuatan album, rencana pementasan, jadwal siaran di media massa elektronik; meminta informasi misalnya unggahan yang menanyakan lokasi konser, prosedur untuk bisa berpartisipasi 
dalam suatu konser; sedangkan yang termasuk menyapa adalah unggahan-unggahan seperti salam kepada orang lain.

Sebagai contoh, penulis menyajikan data dari interaksi antara The Upstairs dan Death Flames di home myspace milik narasumber (musisi dan penggemar laki-laki dan perempuan), dalam beberapa kesempatan. Data disajikan dalam tabel berikut ini.

Tabel 3.

Konten Komunikasi antara Kelompok Musik dengan

Penggemarnya di Akun Myspace

\begin{tabular}{|c|l|c|c|}
\hline \multicolumn{1}{|c|}{ Band } & \multicolumn{1}{|c|}{$\begin{array}{c}\text { Jenis Konten } \\
\text { Komunikasi }\end{array}$} & Jumlah Komentar & Persentase (\%) \\
\hline \multirow{4}{*}{ The Upstairs } & Komentar & 1 & 10 \\
\cline { 2 - 4 } & Memberi Informasi & 4 & 40 \\
\cline { 2 - 4 } & Meminta Informasi & 1 & 10 \\
\cline { 2 - 4 } & Menyapa & 4 & 40 \\
\cline { 2 - 4 } & Jumlah & 10 & 100 \\
\hline \multirow{5}{*}{ Death Flames } & Komentar & 10 & 20 \\
\cline { 2 - 4 } & Memberi Informasi & 5 & 20 \\
\cline { 2 - 4 } & Meminta Informasi & 5 & 20 \\
\cline { 2 - 4 } & Menyapa & 5 & 100 \\
\cline { 2 - 4 } & Jumlah & 25 & 40 \\
\hline
\end{tabular}

Sumber : http://www.myspace.com/theupstairsl, 28 April 2008

http://www.myspace.com/withdeathflame, 22 Oktober 2008

\section{MUSIK DAN KELOMPOK MUSIK DI ERA INTERNET}

Tingkat popularitas yang antara lain ditunjukkan oleh jumlah penggemar (teman) di akun media sosial atau respon-respon yang diberikan lewat interaksi melalui akun media sosial tidak serta merta bisa dijadikan dasar bahwa pengelolaan dan pemanfaatan akun media sosial menjadi satu-satunya faktor atau penyebab mutlak populer-tidaknya suatu kelompok musik. Keberadaan akun jejaring sosial sebagai media promosi dan publikasi serta wahana untuk menunjukkan eksistensi suatu kelompok musik dan daya tarik suatu kelompok yang diperlihatkan dalam pertunjukanpertunjukan mereka memiliki hubungan yang sifatnya dialektis. Bagi sebagian penggemar, bisa jadi mereka pertama kali melihat penampilan The Upstairs dan Death Flames dalam pertunjukan live. Karena suka dengan penampilan kelompok itu, serta diikuti dengan rasa penasaran, mereka kemudian mencari akun media sosialnya untuk mengikuti informasi-informasi tentang idola mereka. Sebaliknya, bisa juga, sebagian penggemar terlebih dahulu mengetahui keberadaan The Upstairs dan Death 
Flameslewat media sosial, lalu tertarik dan mencoba mencari dan menghadiri pertunjukan live mereka. Kendati demikian, seperti yang dikemukakan oleh Steve Jones, Internet penting untuk membangun citra sebuah band untuk kemudian ditampilkan atau dipresentasikan kepada publik penggemarnya (Steve Jones, 2011: 448).

Kemunculan internet beserta layanan media sosial, yang jelas, bisa menjadi wahana publikasi, promosi, dan penyebarluasan karya-karya suatu kelompok musik. Popularitas musisi memang merupakan hal yang tidak dapat dipisahkan ketika mendiskusikan soal musik dan internet (Steve Jones, 2011: 446) Lebih dari itu, kemunculan internetjuga berpengaruh antara lain terhadap pasar serta pola-pola konsumsi musik.

\begin{abstract}
Although the power to influence the market had traditionally rested with the major corporations, consumers became empowered through a technology which facilitated connectivity; the record companies lost control over the copying and distribution of their recordings in the online environment, while end users discovered new ways of consuming and interacting with music, and have increasingly been able to influence the criteria for successful online services (Ian Michael Dobie, 2001: vi).
\end{abstract}

The Upstairs yang sudah memproduksi album dengan label mayor, dalam hal ini Warner Music Indonesia, jika dilihat melalui kondisi akun media sosial Myspace-nya, memang terlihat lebih populer jika dibandingkan dengan Death flames. Tapi, ini bisa jadi bukan alasan utama yang mendasari tingkat popularitas itu. Di era internet seperti sekarang, seperti dikemukakan oleh Dobie di atas, di satu sisi perusahaan rekaman kehilangan kendali atas distribusi karya musik, dan di sisi lain pendengar atau penggemar memiliki daya dan kemampuan untuk menjangkau materi musik yang mereka konsumsi tanpa terlalu banyak (bahkan mungkin sama sekali) dipengaruhi oleh para gatekeeper di dalam perusahaan-perusahaan rekaman. Keberadaan akun media sosial juga membuat interaksi antara penggemar dan musisi/band bisa lebih dekat, dapat berkomunikasi langsung, dan sedikit mengubah kesan "eksklusif" musisi/band yang dulu seolah "tak tersentuh" oleh penggemarnya. Kini, tidak hanya musik yang dapat menjadi bisnis dengan bantuan media sosial dan internet, melainkan juga penggemarnya/fandom (Steve Jones, 2000: 218). Internet merupakan perangkat teknologi sekaligus sebuah tempat kultural bagi para musisi untuk berkarya dan eksis, serta mengejawantahkan nilai filosofi keberadaan mereka melalui karya seni (Ohlendorf, 2016: 9). 


\section{Kesimpulan}

Kehadiran internet sebagai media baru memberikan dampak pada berbagai lini kehidupan, termasuk dalam ranah produksi, konsumsi dan distribusi musik. Layanan situs web atau media sosial untuk - atau yang digunakan oleh-kelompok musik bisa menjadi salah satu media promosi, pubikasi dan diseminasi atas eksistensi dan karyakarya kelompok-kelompok itu. Musisi atau band bisa menggunakan akun media sosial untuk membangun citra menampilkannya kepada para penggemar. Pada tataran tertentu, interkasi yang terjadi antara musisi atau band dengan penggemar di akun media sosial bisa digunakan sebagai salah satu - tapi bukan satu-satunya, apalagi bersifat mutlakalat ukur, bukti, atau indicator popularitas mereka, sebab di akun semacam ini terdapat jejak digital dan statistiknya dapat dengan mudah dicatat.

Internet, dalam hal ini layanan berupa media sosial, juga memunculkan pola interkasi antara musisi/band dengan penggemar yang cukup berbeda dengan pola-pola interkaksi antara kedua pihak ini di masa lalu, yakni ketika internet belum populer sebagai wahana pendukung komunikasi. Kini, penggemar dan idolanya bisa berinteraksi secara lebih dekat, hanya diperantarai oleh akun media sosial. Konten komunikasinya pun beragam, mulai dari sekedar berkomentar, menyapa, menanyakan informasi, hingga info yang memang terkait dengan eksistensi musisi/band. 


\section{Daftar Pustaka}

Akbar, Ali. 2006. Kamus Praktis Internet: Untuk Semua Orang. Semarang: Neomedia Press.

Dobie, Ian Michael. 2001. "The Impact of New Technologies and theInternet on the Music Industry,1997-2001." Disertasi Doktor, Institute for Social Research,School of Music Media and PerformanceUniversity of Salford, Salford, Inggris.

Jones, Steve. 2011. "Music and the Internet." Dalam Mia Consalvo \& Charles Ess, eds. The Handbook of Internet Studies. Oxford: Wiley-Blackwell. 2000. "Music and the Internet." Popular Music Vol. 19, No. 2.

Mazierska, Ewa. 2015. "Introduction: Setting Popular Music in Motion.” Dalam Ewa Mazierska and Georgina Gregory, eds. Relocating Popular Music. New York: Palgrave Macmillan.

Ohlendorf, KristopherR.K. 2016. "On the Internet by Means of Popular Music: The Cases of Grimes and Childish Gambino." Tesis Master of Arts, Graduate Program in Media Studies, the University of Western Ontario. 